\title{
Atmospheric Factors Affecting a Decrease in the Night-Time Concentrations of Tropospheric Ozone in a Low-Polluted Urban Area
}

\author{
Kazimierz Warmiński (iD) Agnieszka Bẹś
}

Received: 23 March 2018 / Accepted: 15 October 2018/Published online: 25 October 2018

(C) The Author(s) 2018

\begin{abstract}
Ozone $\left(\mathrm{O}_{3}\right)$ decomposition in the troposphere is a very important process which prevents excessive $\mathrm{O}_{3}$ accumulation in the air. It is particularly significant on warm summer days which are marked by a high risk of photochemical smog. We used Spearman's rank correlation test to determine relationships between the drop in $\mathrm{O}_{3}$ concentrations over time $\left(-\Delta \mathrm{O}_{3}\right)$, nitrogen oxide (NO), nitrogen dioxide $\left(\mathrm{NO}_{2}\right)$, and total nitrogen oxide $\left(\mathrm{NO}_{\mathrm{x}}\right)$ concentrations and meteorological factors (1-h average) in low-polluted urban area in Olsztyn (northeastern Poland). Nitrogen oxide concentrations were measured continuously by the chemiluminescence method, and $\mathrm{O}_{3}$ concentrations were determined by the UV photometric method. The obtained results suggest that the rate of decomposition of tropospheric $\mathrm{O}_{3}$ is affected mostly by the presence of $\mathrm{NO}_{\mathrm{x}}$, high temperature, and air humidity (positive correlation) as well as by wind speed (negative correlation). Maximum correlation coefficient values were reported between $-\Delta \mathrm{O}_{3}$ and air temperature, $-\Delta \mathrm{O}_{3}$ and absolute air humidity when $\mathrm{NO}_{\mathrm{x}}$ concentrations were low (below 1.0 microgram per cubic meter), reaching 0.271 and 0.243 , respectively. These results indicate that $\mathrm{O}_{3}$ also reacted with air components other than $\mathrm{NO}$ and $\mathrm{NO}_{2}$. Precipitation at average temperature of $<0{ }^{\circ} \mathrm{C}$ did not significantly contribute to a drop in $\mathrm{O}_{3}$ concentrations at night-time.
\end{abstract}

K. Warmiński $(\bowtie) \cdot$ A. Bęś

Department of Chemistry, Research Group of Environmental Toxicology, University of Warmia and Mazury in Olsztyn, Prawocheńskiego 17, 10-720 Olsztyn, Poland

e-mail: kazimierz.warminski@uwm.edu.pl
In the warm season, precipitation slowed down the rate of $\mathrm{O}_{3}$ decomposition, mostly because $\mathrm{NO}_{x}$ were scrubbed by rain. An analysis of seasonal and daily $-\Delta \mathrm{O}_{3}$ fluctuations revealed that $-\Delta \mathrm{O}_{3}$ values were highest in the summer and shortly after sunset in the diurnal cycle.

Keywords Ozone decomposition · Tropospheric ozone · Urban air pollution $\cdot$ Night-time reaction $\cdot$ Nitrogen oxides $\cdot$ Meteorological conditions

\section{Introduction}

High ozone $\left(\mathrm{O}_{3}\right)$ concentrations in the tropospheric layer of the Earth's atmosphere pose a threat to the health of humans and land animals and have an adverse effect on plants (de Wit et al. 2015; Harmens et al. 2016). Episodes of high concentrations of $\mathrm{O}_{3}$, particulate matter (PM10, PM2.5), and nitrogen dioxide $\left(\mathrm{NO}_{2}\right)$ are major current problems related to air pollution. However, it should be stressed that PM10, PM2.5, and $\mathrm{NO}_{2}$ are found mostly in the air in urban and industrial regions, whereas $\mathrm{O}_{3}$ is present not only in urban but also in suburban and rural areas. The maximum daily 8 -h mean concentration of $\mathrm{O}_{3}$ should not exceed $120 \mathrm{\mu g} \mathrm{m}^{-3}$ (long-term objective) or $120 \mathrm{\mu g} \mathrm{m}^{-3}$ on more than 25 days per calendar year (target value) (EU 2008). In Europe, $41 \%$ of all stations showed $\mathrm{O}_{3}$ concentrations above the target value for the protection of human health in 2015 , which is considerably more stations than over the previous 5 years. In addition, only 
$13 \%$ of air quality monitoring stations fulfilled the longterm objective (no exceedance of the threshold level). Eighty-eight percent of the stations with values above the long-term objective were background stations (EEA 2017). Tropospheric $\mathrm{O}_{3}$ is also a greenhouse gas which contributes to global warming (IPCC 2007). In addition to its adverse effect on human health and the natural environment, tropospheric $\mathrm{O}_{3}$ also contributes to significant economic losses by damaging crops, lowering crop yield and causing damage to certain materials, in particular rubber. The annual losses resulting from the above have been estimated at around $€ 6.7$ billion in 47 countries in Europe (Holland et al. 2006).

Large quantities of $\mathrm{O}_{3}$ are formed in the stratosphere. A part of this naturally formed stratospheric $\mathrm{O}_{3}$ goes down to troposphere. However, photochemical processes involving nitrogen oxides $\left(\mathrm{NO}_{\mathrm{x}}\right)$, volatile organic compounds (VOCs), and carbon monoxide (CO) are a more important source of $\mathrm{O}_{3}$ in ground-level ambient air (Sharma et al. 2017). Photochemical smog is the most dangerous phenomenon related to the formation of $\mathrm{O}_{3}$ as a result of the above chemical reactions. In addition to $\mathrm{O}_{3}$, a smoggy atmosphere comprises other characteristic components such as organic oxidizers (including peroxyacetyl nitrate, $\mathrm{PAN}$ ), aldehydes, $\mathrm{NO}_{\mathrm{x}}$, hydrogen peroxide, and free radicals (Kanaya et al. 2007). Photochemical smog is one of the most adverse contributors to the quality of urban air (EEA 2017). Its formation is supported by the following meteorological conditions: high insolation, high temperature, temperature inversion and dry, stagnant air masses (Manahan 2007; Hosoi et al. 2011). This environment triggers intense reactions with sunlight irradiation which produce $\mathrm{O}_{3}$ and other secondary air pollutants. The most important phase of those changes is the $\mathrm{NO}-\mathrm{NO}_{2}-\mathrm{O}_{3}$ inter-conversion cycle which takes place in line with the below equations (Crutzen et al. 1999; Warmiński and Bęś 2009):

$$
\begin{aligned}
& \mathrm{NO}_{2} \stackrel{h v}{\rightarrow} \mathrm{NO}+\mathrm{O} \\
& \mathrm{O}+\mathrm{O}_{2}+\mathrm{M} \rightarrow \mathrm{O}_{3}+\mathrm{M} \\
& \mathrm{NO}+\mathrm{O}_{3} \rightarrow \mathrm{NO}_{2}+\mathrm{O}_{2}
\end{aligned}
$$

where

M molecules which absorb excess energy and determine the stability of $\mathrm{O}_{3}$ molecules (usually $\mathrm{N}_{2}$ or $\mathrm{O}_{2}$ molecules) $h \nu$ photon energy (with electromagnetic wave length of $\lambda=290-430 \mathrm{~nm}$ )

R1-R3 reactions establish a photostationary state equilibrium which is described by the following equation (Leighton 1961):

$\frac{[\mathrm{NO}]\left[\mathrm{O}_{3}\right]}{\left[\mathrm{NO}_{2}\right]}=\frac{J_{\mathrm{NO}_{2}}}{k_{3}}$

where

$J_{\mathrm{NO}_{2}}$ nitrogen dioxide $\left(\mathrm{NO}_{2}\right)$ photolysis rate constant (rate constant of $\mathrm{R} 1$ reaction)

$k_{3} \quad$ nitrogen oxide (NO) oxidation rate constant (rate constant of $\mathrm{R} 3$ reaction)

The above equation demonstrates that all other reactions which reduce $\mathrm{NO}$ concentrations in favor of $\mathrm{NO}_{2}$ increase $\mathrm{O}_{3}$ concentrations. Those reactions are inclusive of photochemical oxidation of $\mathrm{CO}$, methane $\left(\mathrm{CH}_{4}\right)$, and non-methane VOC (Warmiński and Rogalski 2007; Kalbarczyk and Kalbarczyk 2017), namely,

$\mathrm{CO}+2 \mathrm{O}_{2} \stackrel{\mathrm{NO}_{x} h u}{\longrightarrow} \mathrm{CO}_{2}+\mathrm{O}_{3}$

$\mathrm{CH}_{4}+4 \mathrm{O}_{2} \stackrel{\mathrm{NO}_{x} h \nu}{\longrightarrow} \mathrm{HCHO}+2 \mathrm{O}_{3}+\mathrm{H}_{2} \mathrm{O}$

Atmospheric $\mathrm{O}_{3}$ is a relatively unstable gas. It participates in a variety of redox reactions in the atmosphere. Atmospheric $\mathrm{O}_{3}$ reacts with both organic and inorganic compounds (mainly with $\mathrm{NO}, \mathrm{SO}_{2}, \mathrm{CO}, \mathrm{H}_{2} \mathrm{O}$ ) which are in plentiful supply in ground-level air (Crutzen et al. 1999; Hosoi et al. 2011). For this reason, cyclic, diurnal changes are observed in tropospheric $\mathrm{O}_{3}$ levels where maximum concentration values are reported in the afternoon and minimum concentrations are noted in the hours directly preceding sunrise (Mazzeo et al. 2005; Kanaya et al. 2007; Warmiński and Rogalski 2007; Kalbarczyk et al. 2016). It has been suggested that the most important night-time reaction takes place between $\mathrm{O}_{3}$ and NO. As demonstrated by Nicholson et al. (2001), the drop in $\mathrm{O}_{3}$ concentrations in urban air which is characterized by high NO levels is more pronounced in the summer than in the winter. According to our previous research, the $\mathrm{NO}$ oxidation rate constant $\left(\mathrm{k}_{3}\right)$ in the city of Olsztyn (north-eastern Poland) ranged from 22.5 to $27.7 \mathrm{ppm}^{-1} \mathrm{~min}^{-1}$ in July and from 14.1 to $15.5 \mathrm{ppm}^{-1} \mathrm{~min}^{-1}$ in January (Warmiński and Rogalski 2007). According to Mazzeo et al. (2005), 
the $\mathrm{k}_{3}$ constant in Buenos Aires was 21.5 to $23.0 \mathrm{ppm}^{-1} \mathrm{~min}^{-1}$ in wintertime. The reported differences are due to various thermal conditions because $\mathrm{k}_{3}$ is a function of air temperature as demonstrated by the equation (Seinfeld and Pandis 2016):

$k_{3}=3.23 \cdot 10^{3} \exp \left(\frac{-1430}{T}\right)\left(\mathrm{ppm}^{-1} \min ^{-1}\right)$

where $T$ - air temperature (K).

Other redox reactions involving $\mathrm{O}_{3}$ may be predominant at low $\mathrm{NO}_{\mathrm{x}}$ concentrations, subject to the locally occurring gaseous pollutants, aerosols, and water vapor. Therefore, we hypothesized that the rate of decrease in tropospheric $\mathrm{O}_{3}$ is also influenced by factors other than nitrogen oxide concentrations and temperature. The main motivation for the present study was to assess the sensitivity of night-time ozone concentrations to meteorological parameters at different $\mathrm{NO}_{\mathrm{x}}$ levels. The results will be useful for modeling tropospheric ozone concentrations. According to Wałaszek et al. (2018), modeling errors are predominantly systematic and result from chemical mechanisms, meteorological fields, and initial and boundary conditions, including background ozone levels. Reliable estimation of initial ozone concentrations is crucial for reducing ozone modeling errors. Ozone decomposition in the lower atmospheric layer is a very important phenomenon which prevents excessive accumulation of this gas in ambient air, in particular on warm summer days.

\section{Materials and Methods}

\subsection{Location of the Monitoring Site}

The study was conducted at the air quality monitoring station of the University of Warmia and Mazury in Olsztyn. The station's location and the mode of collecting representative air samples are consistent with the requirements set forth in the Regulation of the Polish Minister of Environment of September 3, 2012 and Directive 2008/50/ EC of the European Parliament and of the Council of May 21, 2008 (EU 2008). The city of Olsztyn is situated in north-eastern Poland, in a region which is popularly known as the Green Lungs of Poland (Fig. 1). The region is characterized by a low degree of industrialization and by exceptional environmental values. The main sources of air pollution in Olsztyn are road transport and household gas emissions. The air quality monitoring station is situated in the south-western part of Olsztyn, on Lake Kortowskie. The monitoring site has the following geographic coordinates: $53^{\circ} 45^{\prime} 34.3^{\prime \prime} \mathrm{N}, 20^{\circ} 27^{\prime} 09.5^{\prime \prime} \mathrm{E}$. The nearest sources of pollution are Warszawska street which is a part of national road No. 16 (east-bound, at a distance of approx. $500 \mathrm{~m}$ ), residential estates in Słoneczny Stok composed of single-family houses equipped with coalfired boilers $(1000 \mathrm{~m})$, Dajtki (1400 m), Brzeziny $(1600 \mathrm{~m})$, and the city center $(2200 \mathrm{~m})$.

The results of daily measurements were compared with data from selected air quality monitoring stations of the Chief Inspectorate for Environmental Protection (GIOŚ) to determine spatiotemporal trends in tropospheric $\mathrm{O}_{3}$ and $\mathrm{NO}_{\mathrm{x}}$ levels. The selected monitoring stations are situated in the Region of Warmia and Mazury (northeastern Poland), the Warsaw Metropolitan Area (capital of Poland, central Poland), and the Silesian Metropolitan Area (highly industrialized region in southern Poland). The stations in north-eastern Poland are situated in the cities of Olsztyn, Elblag, Ostróda, Mragowo, and Gołdap. Data were also obtained from a rural background monitoring station in the Borecka Forest (PL0005R Diabla Gora) which is a part of the European Monitoring and Evaluation Program (EMEP). In the Warsaw Metropoli$\tan$ Area, $\mathrm{O}_{3}$ concentrations were presented as the average value from five monitoring stations in Warsaw, and the results from the Silesian Metropolitan Area were averaged based on the data from the cities of Katowice, Zabrze, Tychy, and Dąbrowa Górnicza. The concentrations of $\mathrm{NO}_{\mathrm{x}}$ were measured in nine monitoring stations in each region. Detailed information about monitoring stations and measurements is provided by GIOŚ at http://powietrze.gios.gov.pl.

\subsection{Measurements and Instrumentation}

$\mathrm{NO}$ and $\mathrm{NO}_{2}$ concentrations were measured continuously by the chemiluminescence method, and $\mathrm{O}_{3}$ levels were determined by the UV photometric method (API 200E and API 400E analyzers, Teledyne Advanced Pollution Instrumentation, Inc. USA). The applied methods are consistent with the ISO 7996:1985 and ISO 13964:1998 standards (ISO 1985; ISO 1998), and the analyzers have US EPA certification (USEPA RFNA-1194-099 and USEPA EQOA-0992-087). All analyzers met the requirements of minimum data capture (DC), stipulated by Directive 2008/50/EC (EU 2008). Minimum $\mathrm{DC}_{\text {for }} \mathrm{O}_{3}$ and $\mathrm{NO}_{\mathrm{x}}$ is $90 \%$ in summer and $75 \%$ in winter. In our study, 


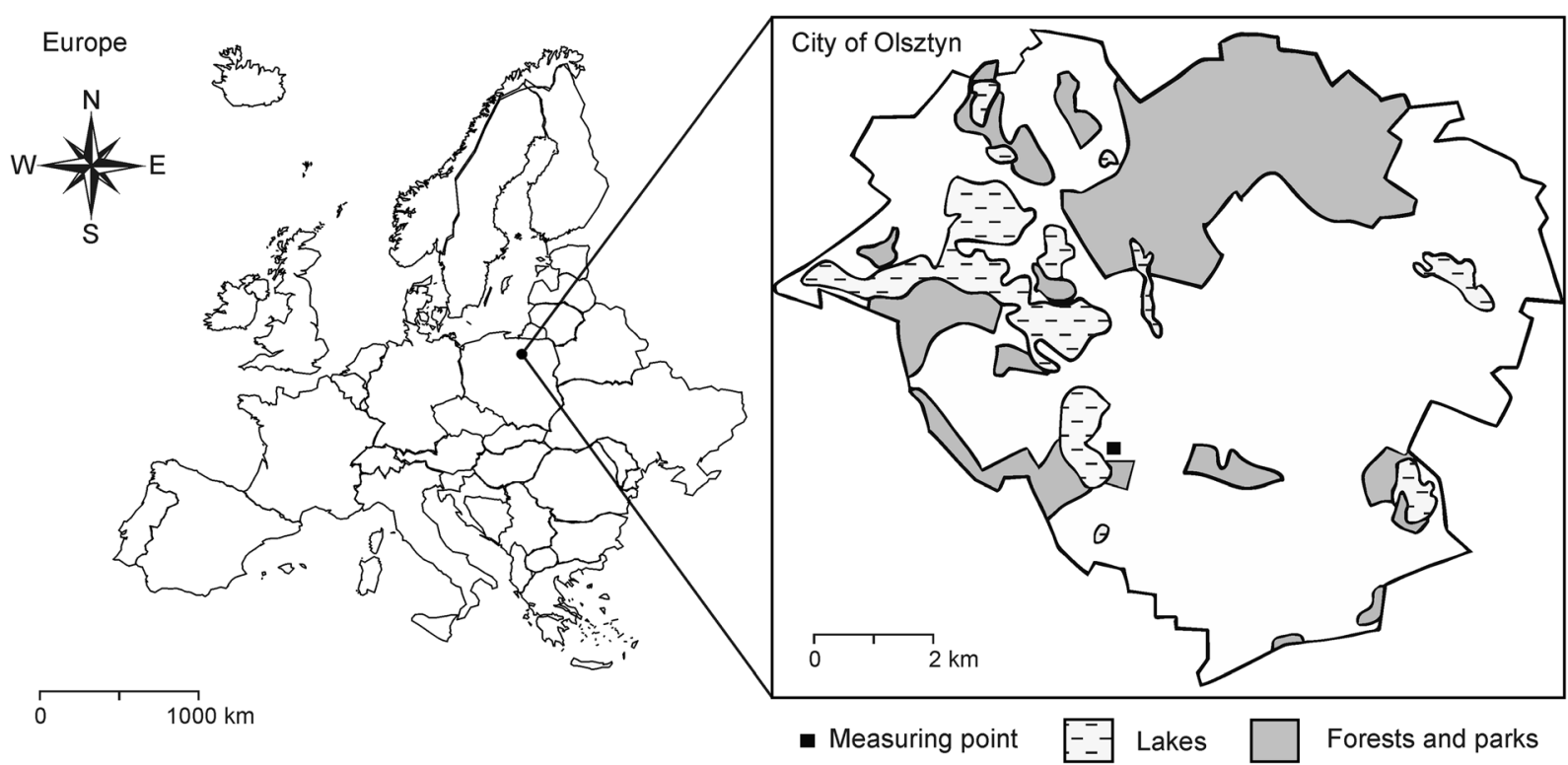

Fig. 1 Location of the city of Olsztyn in Europe and map of Olsztyn with an indication of the measuring point

conducted in 2006, minimum DC was 98.6 and $76.1 \%$ for $\mathrm{O}_{3}$ and 98.5 and $91.1 \%$ for $\mathrm{NO}_{\mathrm{x}}$ in summer and winter, respectively. Air temperature and humidity were measured with the DMA580 digital thermo-hygrometer, wind direction and speed measurements were performed using the DNA502 gonio-anemometer and the DNA511 tacho-anemometer, and precipitation was measured with the DQA031 automated rain gauge (LSI s.p.a., Italy). Instantaneous data (5-s) were registered, validated, and averaged to $1 \mathrm{~h}$ in a datalogger with the CS5 v. 5.3 system (CSMS, Poland). Temporal trends in ground-level $\mathrm{O}_{3}$ and $\mathrm{NO}_{x}$ concentrations in ambient air in low-polluted urban area of the city of Olsztyn are presented in Fig. 2. The concentrations of $\mathrm{O}_{3}, \mathrm{NO}_{2}$, and $\mathrm{NO}$ and meteorological parameters were measured throughout 2006, but this study accounts only for data collected at night-time, when photochemical processes cease and when only reactions leading to $\mathrm{O}_{3}$ decomposition take place.

\subsection{Data Analysis}

We determined the drop in $\mathrm{O}_{3}$ concentrations $\left(-\Delta \mathrm{O}_{3}\right)$ in hour $\mathrm{C}$ with the use of the equation:

$-\Delta O_{3}=-\frac{\Delta x}{\Delta t}=-\frac{x_{B C}-x_{A B}}{t_{C}-t_{B}}\left(\mu \mathrm{g} \mathrm{m}^{-3} \mathrm{~h}^{-1}\right)$

where $x_{A B}, x_{B C}$-average $\mathrm{O}_{3}$ concentration $\left(\mu \mathrm{g} \mathrm{m}^{-3}\right)$ based on instantaneous measurements between hour $\mathrm{A}$ to hour $\mathrm{B}$ and hour $\mathrm{B}$ to hour $\mathrm{C}$; $t_{C}, t_{B}-$ time (h) at hour $\mathrm{C}$ and $\mathrm{B}$ from the beginning of the measurement series.

Validated $\mathrm{NO}, \mathrm{NO}_{2}, \mathrm{NO}_{\mathrm{x}}$, and $\mathrm{O}_{3}$ concentrations and meteorological parameters (ambient air temperature, relative and absolute air humidity, wind speed and direction, total atmospheric precipitation) were subjected to a preliminary statistical analysis to verify the hypothesis on the goodness of fit of value distribution to normal distributions. Kolmogorov-Smirnov and chisquare tests invalidated the above hypothesis. Therefore Spearman's rank correlation test was employed to determine relationships between $-\Delta \mathrm{O}_{3}$ and the investigated factors.

Calculations were performed in several time series: (i) throughout the year (all night-time hours); (ii) hours without atmospheric precipitation; (iii) cool season (period with average weekly temperature of ambient air at night-time $<0{ }^{\circ} \mathrm{C}$; in this study, this criterion was fulfilled over a period of 12 weeks, from 01 Jan. 2006 to 25 Mar. 2006); (iv) warm season (12 warmest weeks in the year, from week 25 to 36, i.e. from 11 Jun. 2006 to 09 Sept. 2006; the average night-time temperature of ambient air in the above period was higher than $13.9{ }^{\circ} \mathrm{C}$ ); (v) only hours during which specific $\mathrm{NO}_{\mathrm{x}}$ concentrations were recorded $(\leq 1.0, \leq 2.0, \leq 3.0$, and $>$ $3.0 \mu \mathrm{g} \mathrm{m}^{-3}$ ).

Coefficients of correlation were calculated, and seasonal and diurnal variations in $-\Delta \mathrm{O}_{3}$ were analyzed. The average weekly value of $-\Delta \mathrm{O}_{3}$ was adopted as the 


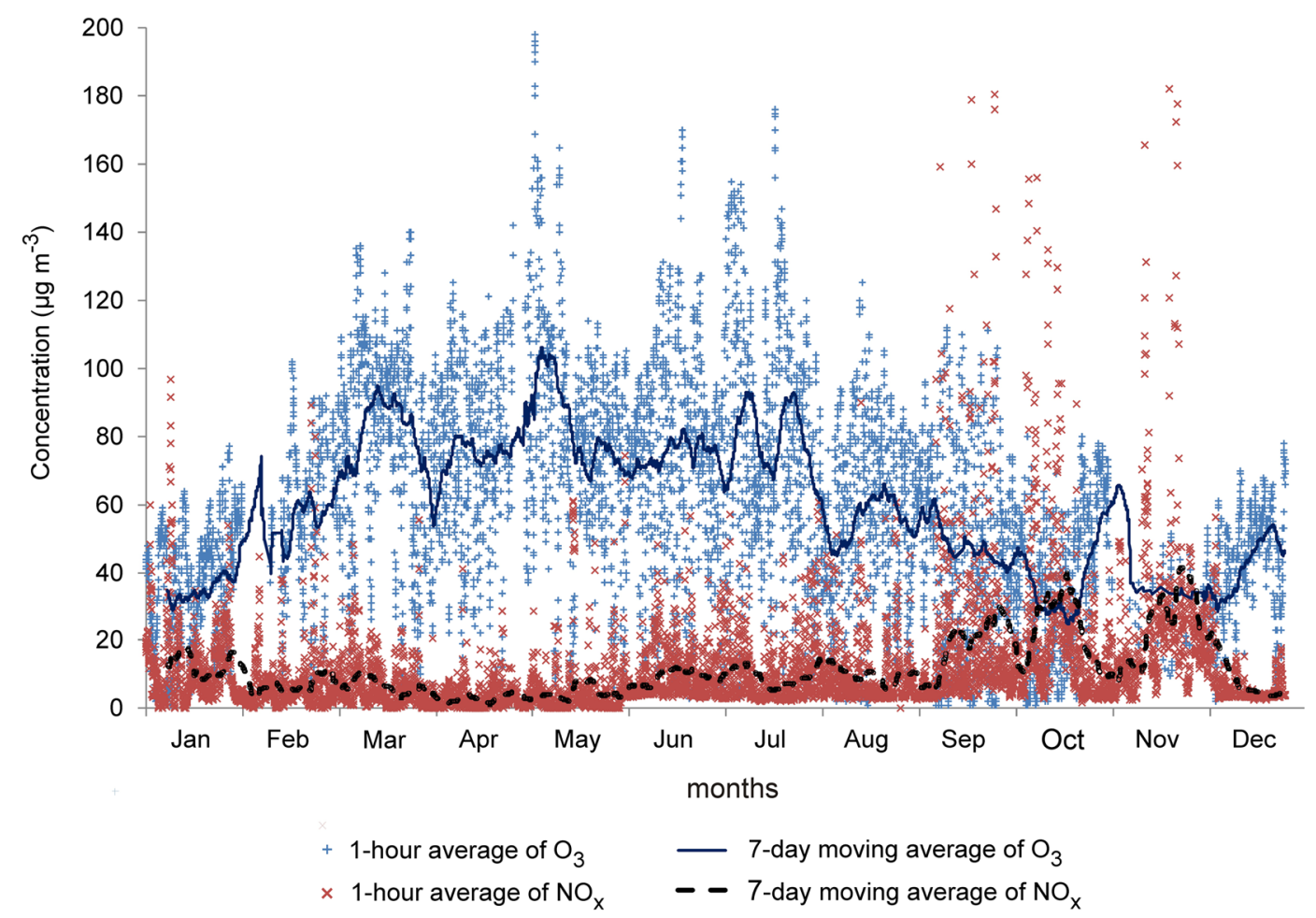

Fig. 2 Temporal trends in ground-level $\mathrm{O}_{3}$ and $\mathrm{NO}_{\mathrm{x}}$ concentrations in ambient air in low-polluted urban area of the city of Olsztyn

dependent variable and the number of the week in the year as the independent variable. Diurnal variation was analyzed separately for the cool and warm season, and the time of the day (independent variable, $x$ ) was transformed in line with the following rules: (i) from sunset to midnight, the values of $x$ for 4 p.m., 5 p.m., 6 p.m., etc. were set at $4,5,6$, etc.; (ii) at midnight, the value of $\times$ was set at 12 ; (iii) from midnight to sunrise, the values of $x$ for 1 a.m., 2 a.m., 3 a.m., etc. were set at 13, 14, 15, etc. The above transformation was performed to ensure the continuity of $x$ value (hours) from sunset to sunrise. The obtained data were verified statistically in STATISTICA 10 software (StatSoft, Inc.).

\section{Results and Discussion}

\subsection{Spatiotemporal Trends in Tropospheric Ozone and Nitrogen Oxide Concentrations in Poland}

The average concentration of tropospheric $\mathrm{O}_{3}$ in all air quality monitoring stations in the Region of Warmia and Mazury (north-east Poland) was lowest in 2016 and highest in 2006 at 48.7 and $56.9 \mu \mathrm{g} \mathrm{m}^{-3}$, respectively (Fig. 3a). A clear decreasing trend in the above parameter was observed in north-east Poland. In our study, the concentration of tropospheric ozone on Lake Kortowskie in Olsztyn decreased from $61.3 \mu \mathrm{g} \mathrm{m}^{-3}$ in 2006 to $54.2 \mathrm{\mu g} \mathrm{m}^{-3}$ in 2008 and exceeded the regional average by $2.4 \mu \mathrm{g} \mathrm{m}^{-3}$. A similar trend was noted in the rural background monitoring station in the Borecka Forest (EMEP station). In contrast, in the monitoring station in downtown Olsztyn, $\mathrm{O}_{3}$ concentration was highest in 2007 at $61.5 \mu \mathrm{g} \mathrm{m}^{-3}$. A comparison of average values for 2006-2008 indicates that $\mathrm{O}_{3}$ levels were around $1 \mu \mathrm{g} \mathrm{m}^{-3}$ lower in central Olsztyn than on Lake Kortowskie. The above was related to differences in the concentration of $\mathrm{NO}_{\mathrm{x}}$ which was around $8 \mu \mathrm{g} \mathrm{m}^{-3}$ higher in central Olsztyn (Fig. 3b). $\mathrm{O}_{3}$ and $\mathrm{NO}_{\mathrm{x}}$ concentrations are measured simultaneously in many locations in Poland and around the world. A negative correlation is observed between ozone and $\mathrm{NO}_{\mathrm{x}}$ levels due to the reaction between $\mathrm{O}_{3}$ and NO (Nicholson et al. 2001; Kalbarczyk et al. 2016). For this reason, ozone levels in industrialized urban areas characterized by higher $\mathrm{NO}_{\mathrm{x}}$ concentrations, such as Warsaw and the Silesian Metropolitan Area, are approximately $10-11 \mu \mathrm{g} \mathrm{m}^{-3}$ lower than in north-eastern Poland. However, a rising trend in the concentrations of both ozone and nitrogen 
a) 65

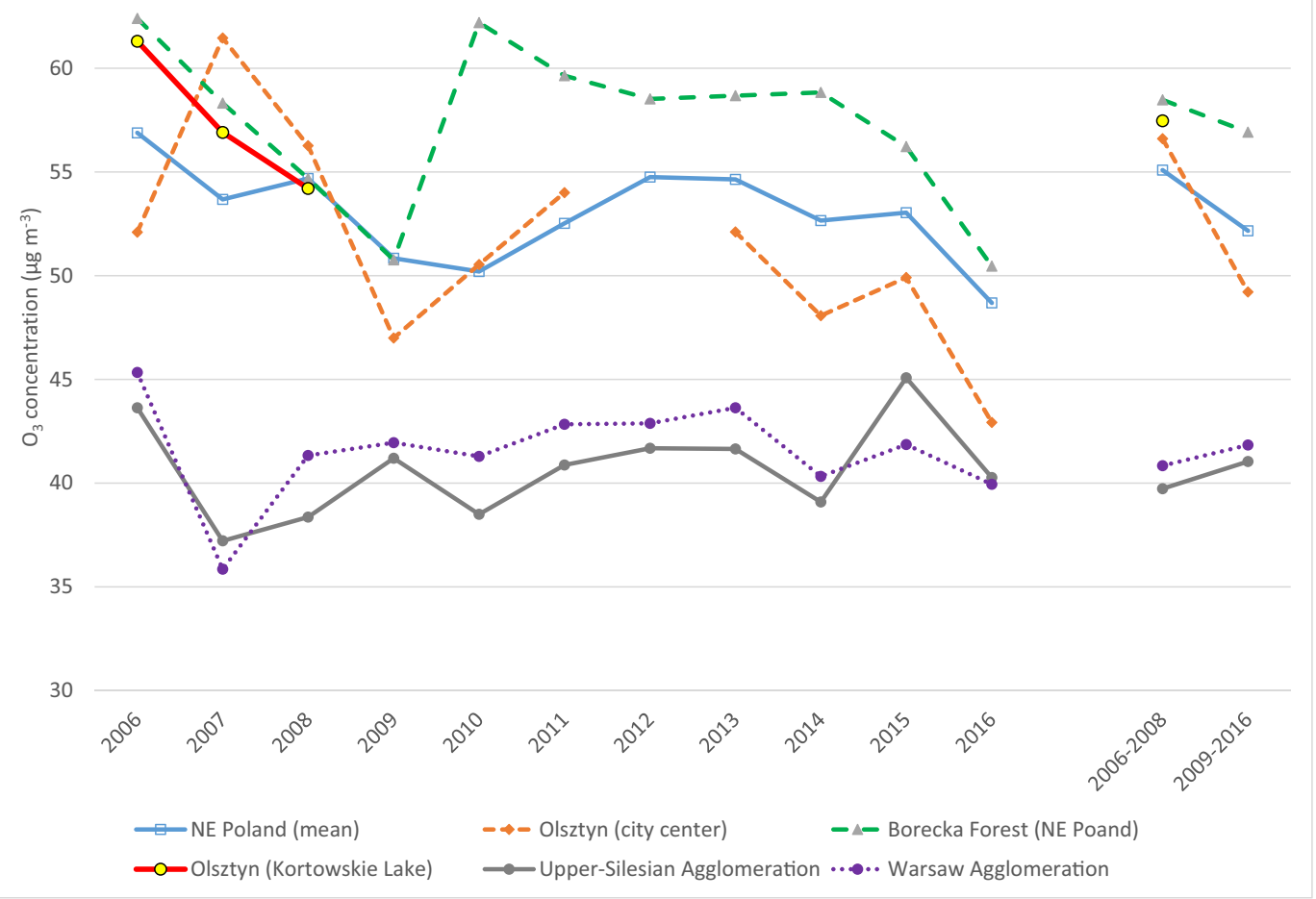

b)

b) 90

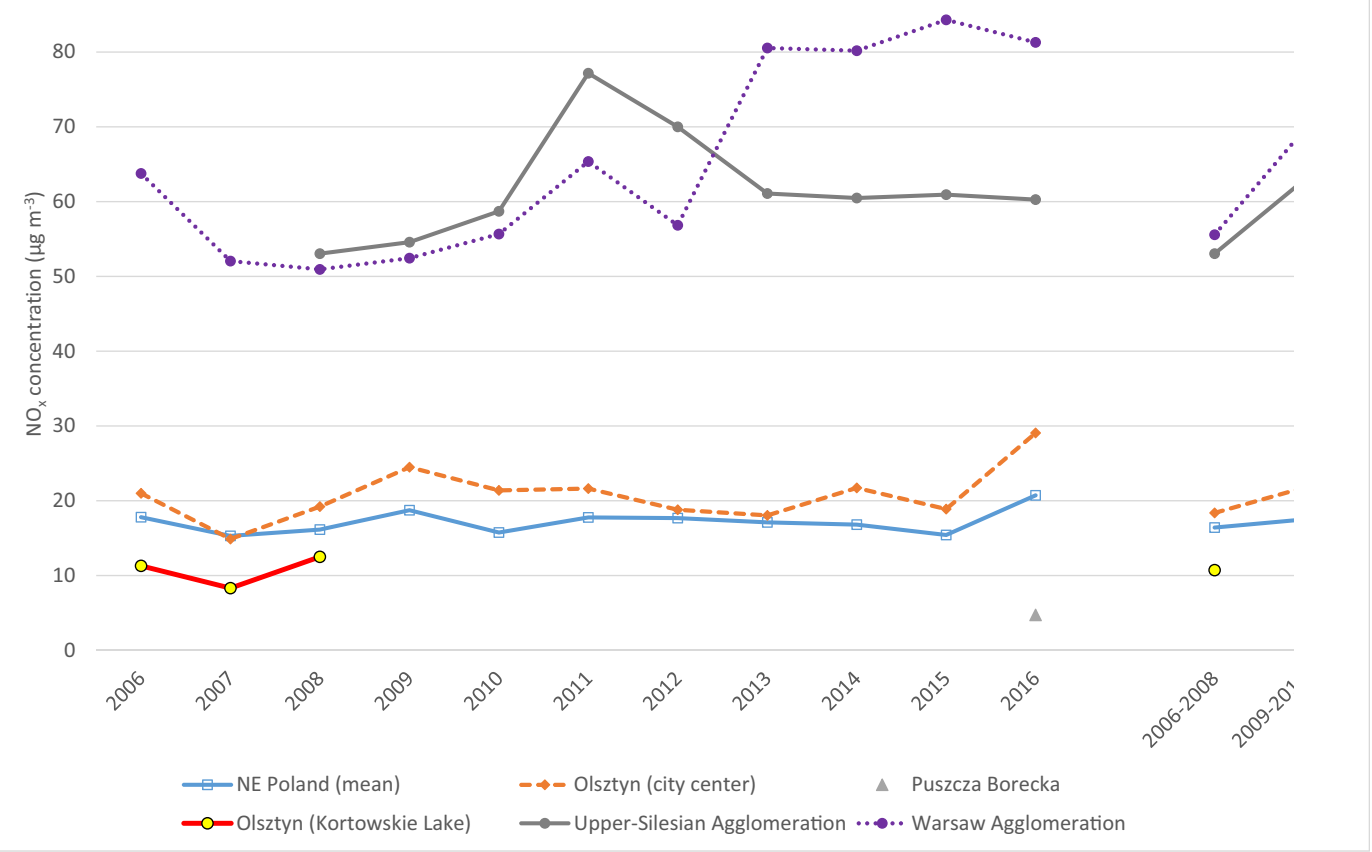

Fig. 3 Spatiotemporal trends in ground-level $\mathrm{O}_{3}$ and $\mathrm{NO}_{\mathrm{x}}$ concentrations in selected urban and rural areas in Poland

oxides has been noted in those locations. Kalbarczyk et al. (2016), Karagiannidis et al. (2015), and Mazzeo et al. (2005) reported similar correlations between $\mathrm{O}_{3}$ and $\mathrm{NO}_{\mathrm{x}}$ levels. 
3.2 Correlations between $-\Delta \mathrm{O}_{3}$ vs. Meteorological

Factors and Nitrogen Oxide Concentration

The key factors which determined the rate of drop in $\mathrm{O}_{3}$ concentrations at night-time were wind speed, total atmospheric precipitation, ambient air temperature, absolute humidity of ambient air, $\mathrm{NO}_{2}$, and $\mathrm{NO}_{\mathrm{x}}$ concentrations (Table 1). Except for wind speed and total atmospheric precipitation, the remaining factors were positively correlated with $-\Delta \mathrm{O}_{3}$. If data from hours with atmospheric precipitation are omitted in the analysis, the influence of chemical factors on the determination of the dependent variable $\left(-\Delta \mathrm{O}_{3}\right)$ decreases, while the impact of meteorological factors increases.

The obtained results supported our assumptions that temperature significantly contributes to a decrease in $\mathrm{O}_{3}$ concentrations. However, no statistically significant correlation was found between the rate of $\mathrm{O}_{3}$ concentration drop and input $\mathrm{O}_{3}$ and $\mathrm{NO}$ concentrations. It could probably be explained by the multifactorial nature of the phenomenon. Moreover, NO concentrations determined at air quality monitoring stations are not input concentrations but the concentrations of $\mathrm{NO}$ which has not yet been oxidized to $\mathrm{NO}_{2}$. At measuring stations situated at least several hundred meters away from $\mathrm{NO}_{\mathrm{x}}$ sources, $\mathrm{NO}$ is largely oxidized to $\mathrm{NO}_{2}$ before it reaches the monitoring station with the air masses (Nicholson et al. 2001; Warmiński and Rogalski 2006). Therefore, $\mathrm{NO}_{\mathrm{x}}$ concentrations are proportional to initial NO concentration levels. For this reason, no statistically significant dependencies were found between $-\Delta \mathrm{O}_{3}$ and $\mathrm{NO}$ levels, but only between $-\Delta \mathrm{O}_{3}$ and $\mathrm{NO}_{2}$ and $\mathrm{NO}_{\mathrm{x}}$ concentrations (Table 1). The formation of $\mathrm{NO}_{3}$ radicals in dark hours is a well-described reaction which leads to a drop in $\mathrm{O}_{3}$ concentrations (Zheng et al. 2017):

$\mathrm{O}_{3}+\mathrm{NO}_{2} \rightarrow \mathrm{NO}_{3}+\mathrm{O}_{2}$

$\mathrm{NO}_{3}$ radicals are determined practically only at nighttime because they rapidly photolyze to $\mathrm{NO}_{2}$ and $\mathrm{O}$ (Atkinson and Arey 2003, Stutz et al. 2010, Wang et al. 2013, Akimoto 2016).

The highest correlation was found between wind speed and $-\Delta \mathrm{O}_{3}$, and the determined dependency was negative. Strong winds cause intense mixing of masses of polluted and clean air; therefore, the higher the wind speed, the greater the drop in $\mathrm{NO}_{\mathrm{x}}$ levels (Table 2). The negative correlation between $\mathrm{NO}_{\mathrm{x}}$ concentrations and wind speed has been documented in the works of, among others, Delaney and Dowding (1998), Tang et al. (2011), Karagiannidis et al. (2015), and Valotto and Varin (2016). For this reason, we determined lower $\mathrm{NO}_{\mathrm{x}}$ concentrations and $-\Delta \mathrm{O}_{3}$ values under strong wind conditions (Tables 1 and 2). A negative correlation between $\mathrm{O}_{3}$ concentrations and wind speed was also reported by Banta et al. (2011) and Kalbarczyk et al. (2016).

A positive correlation between $-\Delta \mathrm{O}_{3}$ and absolute humidity could be due to the reaction between $\mathrm{O}_{3}$ and water in the gaseous state. However, this mechanism of $\mathrm{O}_{3}$ breakdown at night-time is doubtful due to a very low value of the correlation coefficient at 0.133 (Table 1). Other mechanisms could be involved in the decomposition of ground-level ozone, but the reaction with NO (R3) appears to be predominant.

Ozone and particles adsorbed on aerosol surface also react at a faster rate in high humidity air. Chughtai et al. (2003) proposed the following relationship between the drop in $\mathrm{O}_{3}$ concentrations $\left(-\mathrm{d}\left[\mathrm{O}_{3}\right] / \mathrm{dt}\right)$ caused by its reaction with soot aerosol and absolute humidity of air:

$\frac{-d\left[O_{3}\right]}{d t}=k^{\prime \prime}\left[O_{3}\right]^{2} p^{0.2}$

where

$\left[\mathrm{O}_{3}\right]$ ozone concentrations (ppm)

$p \quad$ absolute humidity $(\mathrm{Pa})$

$k^{\prime \prime} \quad$ reaction constant determined by temperature and the type of aerosol surface

Equation 4 indicates that the higher the air humidity, the higher the rate of $\mathrm{O}_{3}$ reaction with soot components. Sakamoto et al. (2004) also noted that the presence of water vapor in air speeds up the oxidation of $\mathrm{SO}_{2}$ through $\mathrm{O}_{3}$ on the surface of yellow sand particles.

Buckley and Birks (1995) also pointed to the possibility of visible-light photolysis of $\mathrm{O}_{3} \cdot \mathrm{H}_{2} \mathrm{O}$ cluster molecules (Van der Waals complexes) as well as reaction without the involvement of solar radiation:

$\mathrm{O}_{3} \cdot \mathrm{H}_{2} \mathrm{O} \stackrel{h v(v i s)}{\longrightarrow} 2 \mathrm{OH}+\mathrm{O}_{2}$

$\mathrm{O}_{3} \cdot \mathrm{H}_{2} \mathrm{O} \stackrel{h v(\text { vis }) / \text { dark }}{\longrightarrow} \mathrm{H}_{2} \mathrm{O}_{2}+\mathrm{O}_{2}$

Reaction R7 is energetically possible for light with a wavelength under $665 \mathrm{~nm}$, while reaction $\mathrm{R} 8$ is exothermic and it takes place even without light absorption, i.e., at night. Those reactions could also be responsible for higher $-\Delta \mathrm{O}_{3}$ values observed at night-time when air humidity is high. 
Table 1 Relationships between $-\Delta \mathrm{O}_{3}$ in night-time and independent variables

$R_{S}$ Spearman's correlation coefficient, $p$ significance level

\begin{tabular}{|c|c|c|c|c|}
\hline \multirow[t]{2}{*}{ Independent variables } & \multicolumn{2}{|c|}{ All night-time hours } & \multicolumn{2}{|c|}{ Night-time hours without precipitation } \\
\hline & $\mathrm{R}_{\mathrm{S}}$ & $\mathrm{p}$ & $\mathrm{R}_{\mathrm{S}}$ & $\mathrm{p}$ \\
\hline $\mathrm{O}_{3}$ concentration & -0.017 & 0.327 & -0.013 & 0.458 \\
\hline NO concentration & 0.029 & 0.087 & 0.032 & 0.069 \\
\hline $\mathrm{NO}_{2}$ concentration & 0.141 & $<0.001$ & 0.134 & $<0.001$ \\
\hline $\mathrm{NO}_{\mathrm{x}}$ concentration & 0.124 & $<0.001$ & 0.119 & $<0.001$ \\
\hline Relative humidity & -0.023 & 0.180 & -0.016 & 0.375 \\
\hline Absolute humidity & 0.133 & $<0.001$ & 0.142 & $<0.001$ \\
\hline Temperature & 0.149 & $<0.001$ & 0.157 & $<0.001$ \\
\hline Wind direction & -0.017 & 0.306 & -0.010 & 0.564 \\
\hline Wind speed & -0.313 & $<0.001$ & -0.323 & $<0.001$ \\
\hline Precipitation amount & -0.058 & 0.001 & - & - \\
\hline Hour of the night & 0.099 & $<0.001$ & 0.098 & $<0.001$ \\
\hline Week of the year & -0.033 & 0.050 & -0.023 & 0.191 \\
\hline
\end{tabular}

Air pollutants, in particular the highly reactive $\mathrm{O}_{3}$, can also undergo dry deposition on the surface of soil, plants, buildings, etc. During the day, in vegetated areas, both stomatal fluxes and non-stomatal fluxes play an important role in the dry deposition of $\mathrm{O}_{3}$. At night, the dry deposition of $\mathrm{O}_{3}$ is dominated by non-stomatal fluxes (Fares et al. 2010; El-Madany et al. 2017). The total dry deposition of $\mathrm{O}_{3}$ is several-fold or 10- to 20fold lower at night than during the day (Padro 1996; ElMadany et al. 2017). According to the literature, stomatal flux is proportional to air humidity (Zapletal et al.
2012; Fares et al. 2013). The night-time concentrations of $\mathrm{O}_{3}$ decrease steadily due to the absence of sunlight and redox reactions.

Total atmospheric precipitation was negatively correlated with $-\Delta \mathrm{O}_{3}$ (Table 1). Although the Spearman's rank correlation coefficient was statistically significant $(p<0.01)$, the precipitation factor in the analysis of annual data did not produce satisfactory results $\left(\mathrm{R}_{\mathrm{S}}=\right.$ $-0.058)$. We propose a hypothesis that this is due to the types of precipitation at various times of the year. The analysis of annual data accounts for total precipitation

Table 2 Results of Spearman's correlation analysis investigating the relationship between chemical parameters of ambient air and meteorological factors in night-time in the cool and warm season

\begin{tabular}{|c|c|c|c|c|c|}
\hline Variables & $\mathrm{AH}$ & $\mathrm{T}$ & WD & WS & $\mathrm{P}$ \\
\hline \multicolumn{6}{|l|}{ Cool season } \\
\hline $\mathrm{O}_{3}$ concentration & $0.284 *$ & $0.397^{*}$ & $0.093 *$ & $0.351 *$ & $-0.104 *$ \\
\hline NO concentration & $-0.109^{*}$ & $-0.145^{*}$ & $-0.209^{*}$ & $-0.126^{*}$ & 0.060 \\
\hline $\mathrm{NO}_{2}$ concentration & $-0.408 *$ & $-0.388^{*}$ & $-0.169 *$ & $-0.482 *$ & -0.036 \\
\hline $\mathrm{NO}_{\mathrm{x}}$ concentration & $-0.412 *$ & $-0.394 *$ & $-0.177^{*}$ & $-0.489 *$ & -0.032 \\
\hline \multicolumn{6}{|l|}{ Warm season } \\
\hline $\mathrm{O}_{3}$ concentration & $0.198^{*}$ & $0.458^{*}$ & $0.241^{*}$ & $0.468 *$ & 0.058 \\
\hline NO concentration & $-0.178^{*}$ & $-0.286^{*}$ & $-0.091^{*}$ & $-0.166^{*}$ & 0.015 \\
\hline $\mathrm{NO}_{2}$ concentration & 0.013 & 0.070 & $-0.271 *$ & $-0.731 *$ & $-0.161^{*}$ \\
\hline $\mathrm{NO}_{\mathrm{x}}$ concentration & -0.017 & 0.026 & $-0.278^{*}$ & $-0.734 *$ & $-0.151^{*}$ \\
\hline
\end{tabular}

Cool season - a period with average weekly temperature of ambient air at night-time of $<0{ }^{\circ} \mathrm{C}$; warm season-12 warmest weeks in the year $A H$ absolute humidity, $T$ temperature, $W D$ wind direction, $W S$ wind speed, $P$ total precipitation

*Spearman's correlation coefficients marked with an asterisk are statistically significant at $p=0.01$ 
which is not broken into different types of precipitation, i.e., rain, snow, or hail. For this reason, we performed an additional analysis of correlation covering two seasons: (i) cool (marked by ambient air temperature below $0{ }^{\circ} \mathrm{C}$; coldest 12 weeks in 2006) and (ii) warm (12 warmest weeks in 2006).

The correlation between $-\Delta \mathrm{O}_{3}$ and total atmospheric precipitation was higher in the warm period $\left(\mathrm{R}_{\mathrm{S}}=-\right.$ $0.113, p<0.001)$ in comparison with data covering the entire year (Table 3). A negative correlation rank coefficient may seem puzzling in this context. It indicates that $\mathrm{O}_{3}$ concentrations decrease at a slower rate as precipitation intensity grows. An analysis of data showed that at times of precipitation over the warm season, $-\Delta \mathrm{O}_{3}$ reaches $1.43 \mu \mathrm{g} \mathrm{m}^{-3} \mathrm{~h}^{-1}$ on average, while it is threefold higher in hours without precipitation (Fig. 4). This is probably due to lower $\mathrm{NO}_{\mathrm{x}}$ concentrations at times of precipitation and, as indicated earlier, NO significantly contributes to a reduction in tropospheric $\mathrm{O}_{3}$ levels. It should be noted that the value of $\mathrm{R}_{\mathrm{S}}$ was very low, although statistically significant. A stronger correlation between $-\Delta \mathrm{O}_{3}$ and $\mathrm{NO}_{2}\left(\mathrm{NO}_{\mathrm{x}}\right)$ concentrations and wind speed was determined in the warm season than in the cool season (Table 3). However, statistically significant correlations between $-\Delta \mathrm{O}_{3}$ and air temperature and between $-\Delta \mathrm{O}_{3}$ and air humidity were not found in either of the analyzed periods.

Table 3 Relationships between $-\Delta \mathrm{O}_{3}$ in night-time and independent variables in the cool and warm season

\begin{tabular}{|c|c|c|c|c|}
\hline \multirow[t]{2}{*}{ Independent variables } & \multicolumn{2}{|c|}{ Cool season } & \multicolumn{2}{|c|}{ Warm season } \\
\hline & $\mathrm{R}_{\mathrm{S}}$ & $\mathrm{p}$ & $\mathrm{R}_{\mathrm{S}}$ & $\mathrm{p}$ \\
\hline $\mathrm{O}_{3}$ concentration & 0.001 & 0.973 & -0.061 & 0.100 \\
\hline NO concentration & 0.038 & 0.237 & 0.021 & 0.567 \\
\hline $\mathrm{NO}_{2}$ concentration & 0.156 & $<0.001$ & 0.273 & $<0.001$ \\
\hline $\mathrm{NO}_{\mathrm{x}}$ concentration & 0.154 & $<0.001$ & 0.262 & $<0.001$ \\
\hline Relative humidity & -0.047 & 0.142 & -0.046 & 0.213 \\
\hline Absolute humidity & -0.064 & 0.045 & 0.069 & 0.060 \\
\hline Temperature & -0.044 & 0.170 & 0.079 & 0.032 \\
\hline Wind direction & 0.065 & 0.042 & -0.068 & 0.064 \\
\hline Wind speed & -0.212 & $<0.001$ & -0.388 & $<0.001$ \\
\hline Precipitation amount & -0.025 & 0.447 & -0.113 & 0.002 \\
\hline Hour of the day & 0.086 & 0.007 & 0.129 & $<0.001$ \\
\hline Week of the year & 0.160 & $<0.001$ & -0.194 & $<0.001$ \\
\hline
\end{tabular}

$R_{S}$ Spearman's correlation coefficient, $p$ significance level
3.3 Influence of $\mathrm{NO}_{\mathrm{x}}$ Concentrations on the Results of Correlation Analysis

Nitrogen oxide concentrations proved to be one of the most important factors determining the rate of the drop in $\mathrm{O}_{3}$ concentrations at night-time. In view of the above, an additional Spearman's rank correlation test was performed for night-time data, and the obtained average $\mathrm{NO}_{\mathrm{x}}$ concentrations were in the range of $\leq 1.0, \leq 2.0, \leq 3.0$, and $>$ $3.0 \mu \mathrm{g} \mathrm{m}^{-3}$. An analysis of correlation test results in Table 4 indicates that selected meteorological factors have a growing impact on $-\Delta \mathrm{O}_{3}$ values as $\mathrm{NO}_{\mathrm{x}}$ concentrations decrease from $>3.0$ to $\leq$ $1.0 \mu \mathrm{g} \mathrm{m}^{-3}$. It applies primarily to temperature and absolute humidity and, to a lesser extent, to wind speed. A reverse dependency was reported for $\mathrm{NO}_{2}$ and $\mathrm{NO}_{\mathrm{x}}$ concentrations.
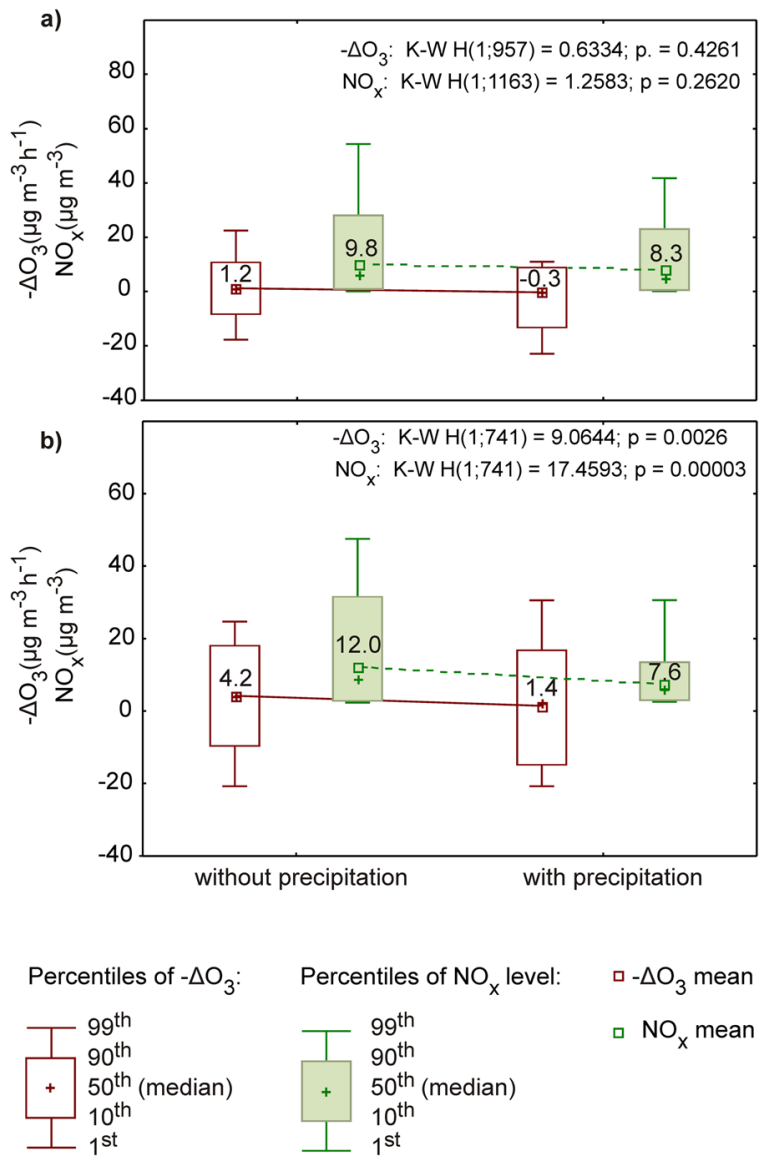

Fig. 4 The effect of atmospheric precipitation on $-\Delta \mathrm{O}_{3}$ and $\mathrm{NO}_{\mathrm{x}}$ concentrations at night-time hours in the cool (a) and warm (b) season 
Table 4 Effect of $\mathrm{NO}_{\mathrm{x}}$ concentrations on the results of Spearman's correlation analysis between $-\Delta \mathrm{O}_{3}$ (dependent variable) and the investigated factors (independent variables)

\begin{tabular}{|c|c|c|c|c|}
\hline \multirow[t]{2}{*}{ Independent variables } & \multicolumn{4}{|c|}{ Spearman's correlation coefficient $\left(\mathrm{R}_{\mathrm{S}}\right)$ for night-time hours with $\mathrm{NO}_{\mathrm{x}}$ concentration within the following ranges } \\
\hline & $\leq 1.0\left(\mu \mathrm{g} \mathrm{m}^{-3}\right)$ & $\leq 2.0\left(\mu \mathrm{g} \mathrm{m}^{-3}\right)$ & $\leq 3.0\left(\mu \mathrm{g} \mathrm{m}^{-3}\right)$ & $>3.0\left(\mu \mathrm{g} \mathrm{m}^{-3}\right)^{\mathrm{a}}$ \\
\hline $\mathrm{O}_{3}$ concentration & -0.019 & -0.098 & -0.014 & 0.004 \\
\hline NO concentration & 0.120 & -0.009 & -0.052 & 0.011 \\
\hline $\mathrm{NO}_{2}$ concentration & 0.019 & 0.093 & $0.115^{*}$ & $0.130^{*}$ \\
\hline $\mathrm{NO}_{\mathrm{x}}$ concentration & 0.057 & 0.078 & 0.042 & $0.123 *$ \\
\hline $\mathrm{NO} / \mathrm{NO}_{\mathrm{x}}$ ratio & 0.154 & 0.019 & -0.038 & $-0.078 *$ \\
\hline Relative humidity & -0.007 & 0.015 & -0.020 & -0.031 \\
\hline Absolute humidity & $0.243 *$ & $0.214^{*}$ & $0.178 *$ & $0.128 *$ \\
\hline Temperature & $0.271 *$ & $0.214 *$ & $0.184 *$ & $0.144 *$ \\
\hline Wind direction & 0.098 & 0.031 & 0.038 & -0.024 \\
\hline Wind speed & $-0.376^{*}$ & $-0.349 *$ & $-0.321 *$ & $-0.306^{*}$ \\
\hline Precipitation amount & -0.085 & -0.030 & -0.082 & -0.057 \\
\hline Hour of the day & 0.103 & 0.097 & 0.067 & $0.098^{*}$ \\
\hline Week of the year & $0.331 *$ & $0.205^{*}$ & $0.173^{*}$ & $-0.091 *$ \\
\hline Number of samples & 172 & 314 & 543 & 2894 \\
\hline
\end{tabular}

* Spearman's correlation coefficients marked with an asterisk are statistically significant at $p=0.01$

${ }^{a}$ Threshold concentration level above which significant correlations between $-\Delta \mathrm{O}_{3}$ and $\mathrm{NO}_{\mathrm{x}}$ concentrations were determined

\subsection{Seasonal and Diurnal Variations of $-\Delta \mathrm{O}_{3}$}

Tables 1, 3, and 4 present Spearman's rank correlation coefficients $\left(\mathrm{R}_{\mathrm{S}}\right)$ and significance levels $(\mathrm{p})$ determined not only between $-\Delta \mathrm{O}_{3}$ and chemical and meteorological factors, but also between $-\Delta \mathrm{O}_{3}$ and the hour of the day and the week of the year. In most cases, those coefficients were statistically significant. Seasonal variations in $-\Delta \mathrm{O}_{3}$ (weekly data) are presented in Fig. 5. Maximum $-\Delta \mathrm{O}_{3}$ values were noted in the summer, whereas minimum $\Delta \mathrm{O}_{3}$ values (near zero) were observed at the beginning and end of the year. The noted difference is due mostly to seasonal variations in air temperature.

In the cool period with temperatures of $<0{ }^{\circ} \mathrm{C}$, diurnal changes in $-\Delta \mathrm{O}_{3}$ values ranged from around -1.0 to $4.0 \mu \mathrm{g} \mathrm{m}^{-3} \mathrm{~h}^{-1}$ (Fig. 6a). Higher fluctuations in $-\Delta \mathrm{O}_{3}$ values were observed in the warm period, from around 1.0 to more than $8.0 \mu \mathrm{g} \mathrm{m}^{-3} \mathrm{~h}^{-1}$ (Fig. 6b). The highest $-\Delta \mathrm{O}_{3}$
Fig. 5 Seasonal variation of $-\Delta \mathrm{O}_{3}$ at night-time hours in 2006 (1-week average and 1-week median)

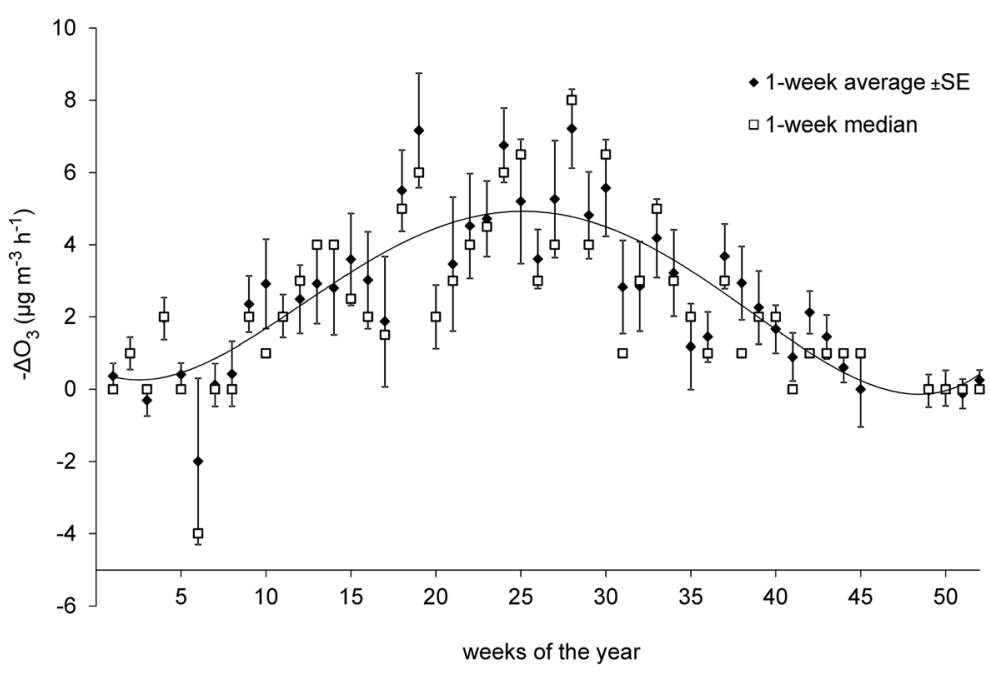


Fig. 6 Diurnal variation of $-\Delta \mathrm{O}_{3}$ and air temperature at night-time in the cool (a) and warm season (b). $x$-value is the transformed night-time hour ( $x=0$ for $12 \mathrm{PM}$ and $x=12$ for 12 AM)
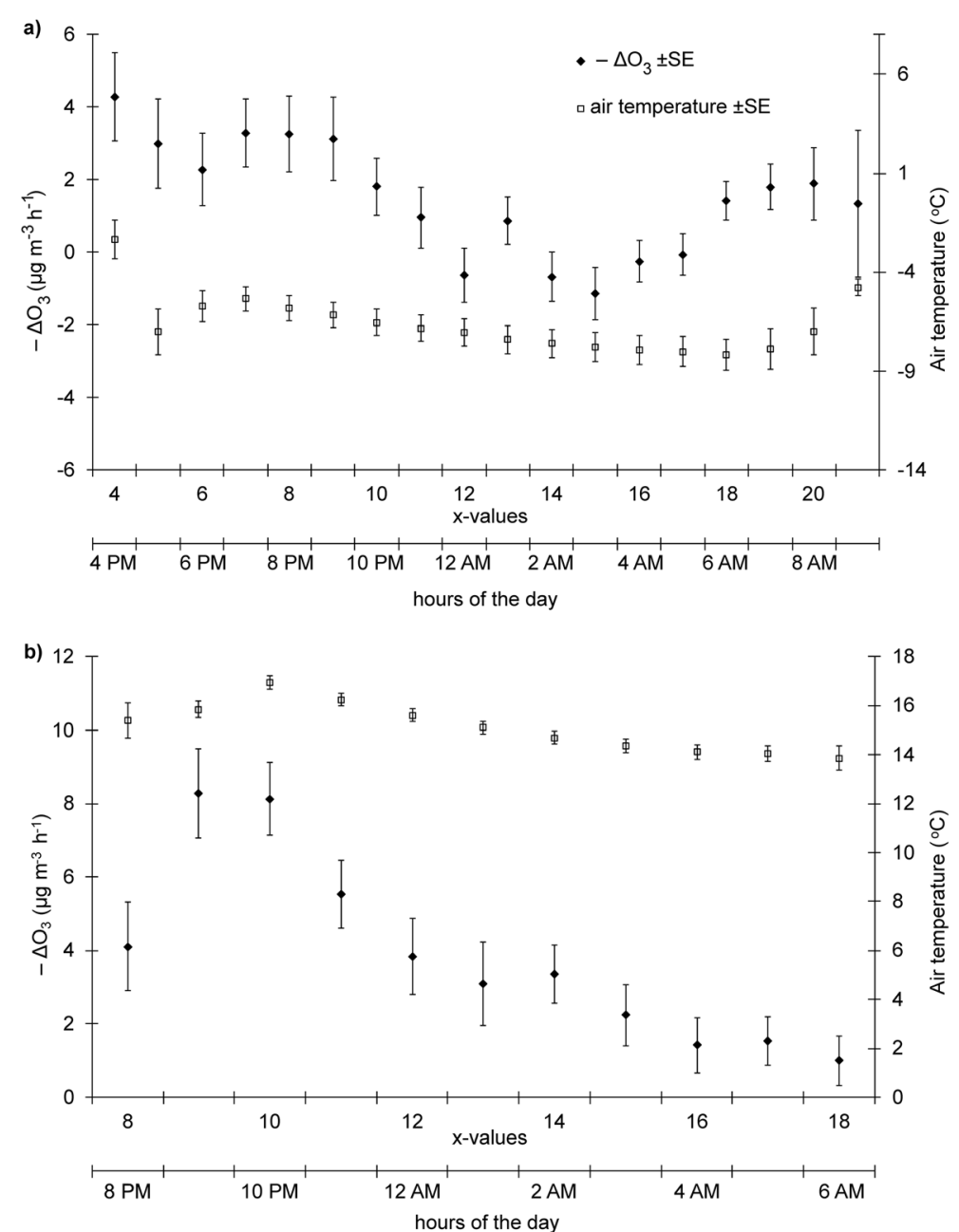

values were recorded between 4 p.m. and 9 p.m. in the cool season and between 9 p.m. and 10 p.m. in the warm season. The highest drop in $\mathrm{O}_{3}$ concentrations is observed in the hours directly after sunset, when air temperature is still relatively high but photochemical processes have already ceased. In the following hours, $-\Delta \mathrm{O}_{3}$ values gradually decrease. $\mathrm{OH}$ and $\mathrm{HO}_{2}$ radical concentrations also begin to decrease as of sunset (Arias and Hastie 1996; Cantrell et al. 1996; Commane et al. 2010).

\section{Conclusions}

Ozone decomposition reactions in the troposphere are an important stage of the $\mathrm{O}_{3}$ cycle. The higher the rate of those reactions, the lower the risk of photochemical smog. The analysis of changes in concentration levels of $\mathrm{O}_{3}$ and other air parameters in the lower parts of the troposphere at night-time supported the preliminary identification of factors which significantly contribute to the rate of those reactions in low-polluted urban area. We conclude that the rate of decomposition of tropospheric ozone $\left(-\Delta \mathrm{O}_{3}\right)$ was affected mainly by the presence of $\mathrm{NO}_{\mathrm{x}}$ and wind speed. It should be noted, however, that $\mathrm{NO}_{\mathrm{x}}$ concentrations were largely determined by wind speed. High wind speed causes intense mixing of air masses, leading to a drop in the concentration levels of pollutants in urban areas, including $\mathrm{NO}_{\mathrm{x}}$. Therefore, wind speed indirectly influenced $-\Delta \mathrm{O}_{3}$. Other significant determinants included air temperature and absolute humidity which were positively correlated with $-\Delta \mathrm{O}_{3}$. Maximum correlation coefficients for these parameters were observed at low $\mathrm{NO}_{\mathrm{x}}$ concentrations in the air $(\leq$ $1.0 \mu \mathrm{g} \mathrm{m}^{-3}$ ), which reached 0.271 and 0.243 , respectively. Both values of $R_{S}$ were similar to the value of $R_{S}$ for $\mathrm{NO}_{\mathrm{x}}$. It should be noted that correlation coefficients were 
low, but statistically significant. The above could suggest that ozone also reacts with air components other than $\mathrm{NO}_{\mathrm{x}}$. The observation that the decrease in ozone concentrations was not correlated with relative humidity, but was correlated with absolute humidity, in particular when $\mathrm{NO}_{\mathrm{x}}$ levels were very low, is a crucial finding. The effect of absolute humidity on $-\Delta \mathrm{O}_{3}$ decreased with a rise in $\mathrm{NO}_{\mathrm{x}}$ levels. Precipitation in the cool season with temperatures of $<0{ }^{\circ} \mathrm{C}$ did not contribute to a drop in $\mathrm{O}_{3}$ concentrations at night-time. In the warm season, rainfalls slowed down the rate at which $\mathrm{O}_{3}$ concentrations decreased, compared with dry spells. This could result from effective removal of $\mathrm{NO}_{\mathrm{x}}$, in particular the highly watersoluble $\mathrm{NO}_{2}$, by rain. $\mathrm{O}_{3}$ is sparingly water-soluble, and its wet deposition takes longer relative to $\mathrm{NO}_{2}$. Seasonal and daily fluctuations in temperature were responsible for $-\Delta \mathrm{O}_{3}$ variations. The highest $-\Delta \mathrm{O}_{3}$ values were reported in the warmest period of the year and shortly after sunset in the daily cycle. The presence of high concentration levels of $\mathrm{OH}$ and $\mathrm{HO}_{2}$ radicals directly after sunset could also be a cause of the observed variations in $-\Delta \mathrm{O}_{3}$ values at that time.

To conclude, it can be postulated that some factors which significantly affect $\mathrm{O}_{3}$ formation during day-time (nitrogen oxides, high air temperature, low wind speed) also contribute to the rate of $\mathrm{O}_{3}$ decomposition at nighttime. For this reason, daily $\mathrm{O}_{3}$ concentration amplitudes are much higher in the summer than at other times of the year. We are also of the opinion that low air humidity during the summer continental high slows down the drop in $\mathrm{O}_{3}$ concentrations at night-time. Day-time weather in the same period is marked by high temperatures and insolation, which supports $\mathrm{O}_{3}$ formation in photochemical processes. Due to the above, $\mathrm{O}_{3}$ concentrations may exceed target value for protection of human health after only several hot summer days and nights with low air humidity.

Our results can be useful for improving tropospheric ozone models. Such models account for ozone forming parameters as well as initial ozone levels (Wałaszek et al. 2018). As demonstrated by the study, selected meteorological parameters and $\mathrm{NO}_{\mathrm{x}}$ levels have a small, but statistically significant effect on initial ozone levels.

Acknowledgments The authors would like to thank Professor Leszek J. Rogalski who initiated an air pollution research program in the city of Olsztyn and promoted the idea of building an air quality monitoring station on the University campus. This study was supported by the Ministry of Science and Higher Education of Poland as part of statutory activities (No. 20.610.027-300).
Open Access This article is distributed under the terms of the Creative Commons Attribution 4.0 International License (http:// creativecommons.org/licenses/by/4.0/), which permits unrestricted use, distribution, and reproduction in any medium, provided you give appropriate credit to the original author(s) and the source, provide a link to the Creative Commons license, and indicate if changes were made.

\section{References}

Akimoto, H. (2016). Atmospheric reaction chemistry. Tokyo: Springer Japan.

Arias, M., \& Hastie, D. (1996). Radical chemistry at the SONTOS site in rural Ontario. Atmospheric Environment, 30(12), 2167-2175.

Atkinson, R., \& Arey, J. (2003). Gas-phase tropospheric chemistry of biogenic volatile organic compounds. A review. Atmospheric Environment, 37(Supplement 2), 197-219.

Banta, R., Senff, C., Alvarez, R., Langford, A., Parrish, D., Trainer, M., et al. (2011). Dependence of daily peak $\mathrm{O}_{3}$ concentrations near Houston, Texas on environmental factors: wind speed, temperature, and boundary-layer depth. Atmospheric Environment, 45(1), 162-173.

Buckley, P., \& Birks, J. (1995). Evaluation of visible-light photolysis of ozone-water cluster molecules as a source of atmospheric hydroxyl radical and hydrogen peroxide. Atmospheric Environment, 29(18), 2409-2415.

Cantrell, C., Shetter, R., \& Calvert, J. (1996). Peroxy radical chemistry during FIELDVOC 1993 in Brittany, France. Atmospheric Environment, 30(23), 3947-3957.

Chughtai, A., Kim, J., \& Smith, D. (2003). The effect of temperature and humidity on the reaction of ozone with combustion soot: implications for reactivity near the tropopause. Journal of Atmospheric Chemistry, 45(3), 231-243.

Commane, R., Floquet, C., Ingham, T., Stone, D., Evans, M., \& Heard, D. (2010). Observations of $\mathrm{OH}$ and $\mathrm{HO}_{2}$ radicals over West Africa. Atmospheric Chemistry and Physics, 10(18), 8783-8801.

Crutzen, P., Lawrence, M., \& Pöschl, U. (1999). On the background photochemistry of tropospheric ozone. Tellus B: Chemical and Physical Meteorology, 51(1), 123-146.

de Wit, H., Hettelingh, J.-P., \& Harmens, H. (2015). Trends in ecosystem and health responses to long-range transported atmospheric pollutants. ICP waters report 125/2015. Norway: Norwegian Institute for Water Research. Oslo.

Delaney, C., \& Dowding, P. (1998). The relationship between extreme nitrogen oxide (NOx) concentrations in Dublin's atmosphere and meteorological conditions. Environmental Monitoring and Assessment, 52(1/2), 159-172.

EEA. (2017). Air quality in Europe - 2017 report. EEA report, no 13/2017. Luxembourg: European Environment Agency, Publications Office of the European Union.

El-Madany, T., Niklasch, K., \& Klemm, O. (2017). Stomatal and non-stomatal turbulent deposition flux of ozone to a managed peatland. Atmosphere, 8(12), 175.

EU. (2008). Directive 2008/50/EC of the European Parliament and of the Council of 21 May 2008 on ambient air quality and 
cleaner air for Europe. Official Journal of the European Union, L 152/1.

Fares, S., McKay, M., Holzinger, R., \& Goldstein, A. (2010). Ozone fluxes in a Pinus ponderosa ecosystem are dominated by non-stomatal processes: evidence from long-term continuous measurements. Agricultural and Forest Meteorology, $150(3), 420-431$.

Fares, S., Matteucci, G., Scarascia Mugnozza, G., Morani, A., Calfapietra, C., Salvatori, E., et al. (2013). Testing of models of stomatal ozone fluxes with field measurements in a mixed Mediterranean forest. Atmospheric Environment, 67, 242251.

Harmens, H., Mills, G., Hayes, F., Sharps, K., \& Frontasyeva, M. (2016). Air pollution and vegetation. ICP Vegetation Annual Report 2015/2016. Bangor: Centre for Ecology and Hydrology.

Holland, M., Kinghorn, S., Emberson, L., Cinderby, S., Ashmore, M., Mills, G., et al. (2006). Development of a framework for probabilistic assessment of the economic losses caused by ozone damage to crops in Europe. ICP Vegetation Report. Bangor: Centre for Ecology and Hydrology.

Hosoi, S., Yoshikado, H., Gaidajis, G., \& Sakamoto, K. (2011). Study of the relationship between elevated concentrations of photochemical oxidants and prevailing meteorological conditions in the North Kanto area, Japan. Water, Air, \& Soil Pollution, 215(1-4), 105-116.

IPCC. (2007). Climate change 2007: the physical science basis. Contribution of Working Group I to the Fourth Assessment Report of the IPCC. Intergovernmental Panel on Climate Change. Cambridge and New York.

ISO. (1985). Ambient air- determination of the mass concentration of nitrogen oxides - chemiluminescence method. ISO 7996:1985. International Organisation for Standardisation. Geneva.

ISO. (1998). Air quality — determination of ozone in ambient airultraviolet photometric method. ISO 13964:1998. International Organisation for Standardisation. Geneva.

Kalbarczyk, R., \& Kalbarczyk, E. (2017). Variability and temporal structure of concentrations of carbon monoxide in Poznań (Central-Western Poland). Journal of Elementology, 22(2), 697-711.

Kalbarczyk, R., Sobolewski, R., \& Kalbarczyk, E. (2016). Biometeorological determinants of the tropospheric ozone concentration in the suburban conditions of Wroclaw, Poland. Journal of Elementology, 21(3), 729-744.

Kanaya, Y., Tanimoto, H., Matsumoto, J., Furutani, H., Hashimoto, S., Komazaki, Y., et al. (2007). Diurnal variations in $\mathrm{H}_{2} \mathrm{O}_{2}, \mathrm{O}_{3}, \mathrm{PAN}, \mathrm{HNO}_{3}$ and aldehyde concentrations and $\mathrm{NO} / \mathrm{NO}_{2}$ ratios at Rishiri Island, Japan: potential influence from iodine chemistry. The Science of the Total Environment, 376(1-3), 185-197.

Karagiannidis, A., Poupkou, A., Giannaros, T., Giannaros, C., Melas, D., \& Argiriou, A. (2015). The air quality of a Mediterranean urban environment area and its relation to major meteorological parameters. Water, Air, \& Soil Pollution, 226(1), 2239.

Leighton, P. (1961). Photochemistry of air pollution. New York: Academic Press.

Manahan, S. (2007). Environmental science and technology. A sustainable approach to green science and technology. Boca Raton: CRC Press/Taylor \& Francis.
Mazzeo, N., Venegas, L., \& Choren, H. (2005). Analysis of NO, $\mathrm{NO}_{2}, \mathrm{O}_{3}$ and $\mathrm{NO}_{\mathrm{x}}$ concentrations measured at a green area of Buenos Aires City during wintertime. Atmospheric Environment, 39(17), 3055-3068.

Nicholson, J., Weston, K., \& Fowler, D. (2001). Modelling horizontal and vertical concentration profiles of ozone and oxides of nitrogen within high-latitude urban areas. Atmospheric Environment, 35(11), 2009-2022.

Padro, J. (1996). Summary of ozone dry deposition velocity measurements and model estimates over vineyard, cotton, grass and deciduous forest in summer. Atmospheric Environment, 30(13), 2363-2369.

Sakamoto, K., Takada, H., \& Sekiguchi, K. (2004). Influence of ozone, relative humidity, and flow rate on the deposition and oxidation of sulfur dioxide on yellow sand. Atmospheric Environment, 38(40), 6961-6967.

Seinfeld, J., \& Pandis, S. (2016). Atmospheric chemistry and physics: From air pollution to climate change. Hoboken: Wiley.

Sharma, S., Sharma, P., \& Khare, M. (2017). Photo-chemical transport modelling of tropospheric ozone: a review. Atmospheric Environment, 159, 34-54.

Stutz, J., Wong, K., Lawrence, L., Ziemba, L., Flynn, J., Rappenglück, B., et al. (2010). Nocturnal $\mathrm{NO}_{3}$ radical chemistry in Houston, TX. Atmospheric Environment, 44(33), 4099-4106.

Tang, L., Rayner, D., \& Haeger-Eugensson, M. (2011). Have meteorological conditions reduced $\mathrm{NO}_{2}$ concentrations from local emission sources in Gothenburg? Water, Air, \& Soil Pollution, 221(1-4), 275-286.

Valotto, G., \& Varin, C. (2016). Characterization of hourly NOx atmospheric concentrations near the Venice international airport with additive semi-parametric statistical models. Atmospheric Research, 167, 216-223.

Wałaszek, K., Kryza, M., \& Werner, M. (2018). The role of precursor emissions on ground level ozone concentration during summer season in Poland. Journal of Atmospheric Chemistry, 75, 181-204.

Wang, S., Shi, C., Zhou, B., Zhao, H., Wang, Z., Yang, S., et al. (2013). Observation of $\mathrm{NO}_{3}$ radicals over Shanghai, China. Atmospheric Environment, 70, 401-409.

Warmiński, K., \& Bęs, A. (2009). Diurnal and seasonal variations in the $\mathrm{NO}_{2}$ photolysis rate constant, $\mathrm{NO}$ titration rate constant and the $\mathrm{NO}_{2} / \mathrm{NO}$ ratio in ambient air in the City of Olsztyn. Ecological Chemistry and Engineering A, 16(8), 1029-1037.

Warmiński, K., \& Rogalski, L. (2006). Wind direction as a determinant of nitric oxide and nitrogen dioxide imission. Zeszyty Problemowe Postepow Nauk Rolniczych, 513, 517-525 (in polish).

Warmiński, K., \& Rogalski, L. (2007). Analysis of photochemical reactions of ozone and its precursors in the troposphere in the summer and winter periods. Polish Journal of Environmental Studies, 16(3B), 497-502.

Zapletal, M., Pretel, J., Chroust, P., Cudlín, P., Edwards-Jonášová, M., Urban, et al. (2012). The influence of climate change on stomatal ozone flux to a mountain Norway spruce forest. Environmental Pollution, 169, 267-273.

Zheng, S., Singh, R., Wu, Y., \& Wu, C. (2017). A comparison of trace gases and particulate matter over Beijing (China) and Delhi (India). Water, Air, \& Soil Pollution, 228(5), 181. 